\section{THE CLEVELAND MEETING OF THE AMERICAN ASSOCIATION.}

THE sixty-fourth meeting of the American Association for the Advancement of Science was held in Cleveland, Ohio, from December 30, 1912, to January 4, I913, under the presidency of Prof. E. C. Pickering, director of the Harvard College Observatory. The meetings of the association were accompanied, as usual, by the meetings of a large number of affiliated societies of national scope but of specific object. Twenty-five such societies met this year in Cleveland at the same time, and, in part, in close cooperation with the eleven sections of the American Association.

The meetings were held in the buildings of the Western Reserve University and of the Case School of Applied Science, which, with the exception of the Medical College of the Western Reserve University, stand upon the same campus in the eastern part of the city. The facilities for the meetings were admirable, and have seldom been excelled in the history of such meetings. There were about one thousand scientific men and women in attendance, or about one-half the attendance of the Washington meeting of last year, which is accounted for by the fact that while Cleveland is a large city and a manufacturing and commercial centre, it has not the large museums and scientific organisations of Washington. Nevertheless, some of the meetings were more largely attended than last year. The physicists, for example, and the psychologists, as well, held the largest sessions in their history, and most of the meetings were marked by exceptionally full programmes of great interest.

The growing tendency of the past few years to emphasise the work of the affiliated societies, more or less at the expense of the sections themselves, was in evidence, and the recent movement was continued whereby it has been arranged that when a national scientific society corresponding in its subject with a given section meets with the association, the sectional programme is abandoned except for a session of general interest, other papers offered to the section being transferred to the corresponding society. It is an interesting movement, and quite different from the general tendency in the British Association.

The titles of the addresses of the retiring vicepresidents of the different sections were as follows:Section A Mathematics and Astronomy, "The Spectroscopic Determination of Stellar Velocities, considered Practically," by Dr. E. B. Frost, Yerkes Observatory, Williams Bay, Wisconsin; Section $B$, Physics, "Unitary Theories in Physics," by Dr. R. A. Millikan, University of Chicago, Chicago, Illinois; Section E, Geology and Geography, "The Significance of the Pleistocene Molluscs," by Dr. B. Shimek, State University of Iowa, Iowa City, Iowa; Section F, Zoology, "Is it Worth While?" by Dr. H. F. Nachtrieb, University of Minnesota, Minneapolis, Minnesota; Section G, Botany, "The Scope of State Natural History Surveys," by Dr. F. C. Newcombe, University of Michigan, Ann Arbor, Michigan; Section $H$, Anthropologv and Psychology, "The Study of Man," by Dr. G. T. Ladd, Yale University, New Haven, Conn.; Section I, Social and Economic Science, "The Comparative Measurements of the Changing Cost of Living," by Dr. J. P. Norton, Yale University, New Haven, Conn.; Section K, Physiology and Experimental Medicine, "The Function of Individual Cells in Nerve Centres," by Dr. W. T. Porter, Harvard Medical School, Boston, Mass.; Section L, Education, "Educational Diagnosis," by Dr. E. L. Thorndike, Columbia University.

In a number of instances, the meetings for the No. 2256 , voL. 907 delivery of the vice-presidential addresses were arranged with following symposia often in joint session between one or more societies and sections on subjects closely related to the subjects of the vicepresidential addresses. In Section G (Botany), an interesting symposium was held on permeability and osmotic pressure, the leading paper on this title being presented by Dr. Jacques Loeb, now of Columbia University. To this discussion, Dr. H. C. Jones contributed a paper on the bearing of osmotic pressure on the development of physical or general chemistry Dr. W. J. V. Osterhout discussed the permeability of plant cells; and Dr. B. E. Livingston discussed the part played by osmotic pressure and related forces as environmental factors.

Section B (Physics) and the American Physical Society presented as a joint interest programme papers on photographing and analysing sound waves, by Dr. D. C. Miller, of the Case School of Applied Science, Cleveland, Ohio; the reaction of the room on the source of sound, by Dr. W. C. Sabine, Harvard University, Cambridge, Mass.; and some points concerning absolute measurements of sound, by Dr. A. G. Webster, Clark University, Worcester, Mass.

The programme of Section I (Social and Economic Science) was largely devoted to conservation topics, one day being given to a symposium on the conservation of human life and health. The American Association of Anatomists and the American Physiological Society had especially long and interesting programmes. The American Society of Zoologists divided its programme into sections on the following topics : ecology and behaviour; comparative anatomy; comparative physiology; embryology and development; cytology; and genetics.

The American Chemical Society, an organisation of great strength, this year for the first time in many years has decided not to meet at the same time and place with the American Association. This is a new policy which will be given a trial. The Chemical Section of the association (Section C) will, it is hoped, continue its activities, but at the present meeting the address of the vice-president was not given. Owing to the absence, on account of ill-health, of the vicepresident of Section D (Mechanical Science and Engineering), no address was, delivered before this section.

At the opening meeting, the retiring president, Dr. C. E. Bessey, of the University of Nebraska, Lincoln, Nebraska, introduced the president-elect, Prof. E. C. Pickering, and addresses of welcome were delivered by Mayor Baker, of Cleveland, by President C. F. Thwing, of the Western Reserve University, and by Acting-President Comstock, of the Case School of Applied Science. President Pickering responded to these addresses of welcome, and was followed by Dr. Bessey with his address as the retiring vice-president, the title of the address being "Some of the Next Steps in Botany." This opening session was held in the large ball-room of the Hotel Statler, and was followed by a reception tendered by the local committee.

At the meeting of the general committee, Atlanta, Georgia, was chosen as the place of the next meeting during Convocation Week, 1913-14 (the week in which the first day of January falls), and Philadelphia was recommended as the place of meeting for the following year. Arrangements were made to make an earnest effort to bring about a large and important meeting in the summer of $19 I_{5}$ on the Pacific coast during the International Exposition to be held at San Francisco to celebrate the opening of the Panama Canal.

The following officers were elected for the year 1913:--President, Dr. E. B. Wilson, Columbia University, New York, N.Y.; vice-presidents: Section A. 
F. Schlesinger, Allegheny Observatory, Allegheny, Pa. ; Section B, A. D. Cole, Ohio State University, Columbus, Ohio; Section C, A. A. Noyes, Massachusetts Institute of Technology, Boston, Mass.; Section $D$, O. P. Hood, U.S. Bureau of Mines, Washington, '.C.; Section E, J. S. Diller, U.S. Geological Survey, Washington, D.C. ; Section F, A. G. Mayer, Carnegie Institution of Washington, Washington, D.C.; Section $G, H$. C. Cowles, University of Chicago, Chicago, Illinois; Section H, W. B. Pillsbury, University of Michigan, Ann Arbor, Michigan; Section I (no election); Section $K$ (no election); Section $L, P$. P. Claxton, U.S. Commissioner of Education, Washington, D.C. General secretary, H. W. Springsteen, Western Reserve University, Cleveland, Ohio; secretarv of the council, W. A. Worsham, jun., University of Georgia, Athens, Georgia.

The following are the new secretaries of the sections elected for five-year terms:-Section A, F. R. Moulton, University of Chicago, Chicago, Illinois; Section $B$ W. J. Humphreys, Weather Bureau, U.S. Department of Agriculture, Washington, D.C. ; Section C (no election); Section D, A. H. Blanchard, Columbia University, New York, N.Y.; Section E, G. F. Kay, Iowa State University, Iowa City, Iowa; Section $F$, H. V. Neal, Knox College, Galesbury, Illinois; Section G, W. J. V. Osterhout, Harvard University, Cambi idge, Mass.; Section H, G. G. MacCurdy, Yale University, New Haven, Conn.; Section I, S. C. Loomis, New Haven, Conn.; Section $K$ (no election); Section L, S. A. Courtis, Home and Day School, Detroit, Michigan.

\section{SCIENCE AT RECENT EDUCATIONAL CONFERENCES.}

TWENTY conferences were held in London during the first fortnight of this month, but we need only refer to the proceedings of the Public School Science-masters, the Teachers' Guild, the Assistantmistresses, the Domestic Science Teachers, and the London County Council Conference of Teachers. It is true that the Headmasters' Conference met in December; but it is a remarkable fact that although individually the members are men of great force directed with earnestness, the vectorial addition of their forces when combined in conference yields a resultant which tends to zero. As their proceedings have no direct bearing upon science teaching, no further reference need be made to them here.

The usual meetings of the Association of Public School Science-masters (A.P.S.S.M.) were held at the London Day Training College, and were preluded by four lectures given by Dr. T. P. Nunn on the theory of science teaching, $w$ th special reference to the conditions in boys' scho ls. Dr. Nunn held that the aim of science teaching was to take the pupil along one of the main roads of human progress. The disciplinary value of science teaching was that they were treading the pathways of great minds, the function of the school being to bring the pupil into sympathetic relation with the character of human effort. He went on to deal with the characteristics of scientific method at different stages of its development; with the nature of induction and deduction, postulate, hypothesis, law and principle. The correlation of science with mathematics and other branches of the school curriculum was illustrated by applying the principles advocated to particular topics, and the skill and ingenuity of the applications were warmly applauded by an audience composed of experienced science-masters.

The main meeting opened with a presidential address by Sir Archibald Geikie, Pres.R.S., who gave NO. 2256, VOL. 90] a retrospect based on his personal observation of the progress of science in public schools during the last sixty years. An abridgment of the address was published in NaTURE of January 16.

The first afternoon was devoted to the discussion of the aims and uses of school science societies, and the topics were assigned to opening speakers, who gave in each cas? a very useful account of the practical managemen General prit ciples and methods were discussed, and next the subjects of field work in zoology and geology. The possibilities of a school astronomical society were brought forward by Mr. G. Hewlett (Rugby), and the Dulwich College Photographic Society was described with reference to details of organisation. It is a striking indication of the spirit animating members of the A.P.S.S.M. that no mention was made of the large amount of voluntary work which these societies place on the shoulders of the busy sciencemaster; this voluntary burden is accepted as a matter of course, and nothing said. One who is merely an onlooker may direct attention to this spirit.

The discussion on practical examinations in science was unsatisfying. Mr. Berridge made some good points in his censure of the weaknesses of examiners; but the objections to abolishing practical examinations of matriculation (or lower) standard lacked a spokesman. Probably some profit would accrue to the crammerat the expense of the schools. Mr. Berridge's suggestion that "a certificate from some responsible person, stating that a given number of hours have been spent in practical work, should be exacted from all candidates before they are allowed to sit for a paper in science," may be intended as a safeguard, but its operation is uncertain. It would be much easier for examining authorities merely to drop practical examinations, and there is a danger that this may be done without requiring Mr. Berridge's certificate. No resolution was put before the meeting, and the time for discussion was too short.

Valuable papers were submitted on the teaching of mechanics by Mr. A. W. Siddons (Harrow), Mr. C. E. Ashford (Dartmouth), and Mr. W. J. Dobbs. All advocated procedure from experiment and intuition to theory of increasing rigour; from concrete to abstract. The outcome of the discussions during recent years at the A.P.S.S.M. and the Mathematical Association will be, we hope, that the experimental and logical treatment will be unified. Formerly boys learnt "mechanics" in the mathematical class-room under one teacher, and another subject, also called "mechanics," in the physical laboratory, without correlation. We have got as far as correlation, and are now hoping for unity. Mr. G. F. Daniell urged that the teaching of density should be put into the background, and that specific volume should be given priority. He proposed the term "roomage" (already used in the Navy) in place of specific volume. The suggestions were favourably received. The value of the historical sequence in teaching chemistry was urged by the Rev. T. J. Kirkland. Mr. W. D. Eggar drew an amusing sletch of the historical sequence in electricity, but put in a strong plea for employing the method in leading the student to understand the work of Galileo, Pascnal, and Newton. He claimed that to trace the development of ideas which culminated in Newton's discoveries was to open a new vista in the intellectual outlook, and ought to form part of any liberal education.

The association continues to increase in membership, and has just originated a useful piece of work by publishing a selected list of science books suitable for school libraries. There was the usual admirable exhibition of apparatus, the influence of which extends 